Bangladesh J. Zool. 49 (2): 215-228, 2021

ISSN: 0304-9027

eISSN: $2408-8455$

\title{
PREVALENCE OF SOME COMMON HUMAN TRAITS: AN UPDATED SURVEY REPORT FROM RAJSHAHI UNIVERSITY CAMPUS, BANGLADESH
}

\author{
M. Saiful Islam*, Al Amin Shams, Shirina Akter and Beauty Biswas \\ Genetics and Molecular Biology Laboratory, Department of Zoology, University of \\ Rajshahi, Rajshahi 6205, Bangladesh
}

\begin{abstract}
Prevalence of some common human traits viz., body weight, height and body mass index (BMI), pattern baldness, body hair, chin, colour blindness, cheek dimples, earlobes, length of index finger, lips, nose, polydactyly, tongue and widow's peak, and ABO blood groups along with their Rh-D antigen, were recorded and analyzed from 500 male and 1000 female students of the Rajshahi University (RU) Campus. Results showed that body weights of the male students $(66.42 \pm 8.92$ $\mathrm{kg})$ were significantly higher $(\mathrm{t}=35.14 ; \mathrm{P}<0.001)$ than those of the female students $(51.64 \pm 6.97 \mathrm{~kg})$. The differences in BMI between males $(23.32 \pm 3.26)$ and females (20.85 \pm 2.63$)$, as expected, were also highly significant $(\mathrm{t}=15.79 ; \mathrm{P}<0.001)$ and notably, some of the female students were underweight $(\mathrm{BMI}<18.5)$. No female had baldness compared to $15.8 \%$ bald males. Sparse body hair was prevalent over the dense body hair in both genders. The females had much higher smooth chin $(89.6 \%)$ than the males $(58.0 \%)$ but the males had much higher cleft chin $(42.0 \%)$ compared to the females $(10.4 \%)$. No female was colourblind whereas $7.4 \%$ males were colourblind. Absence of dimples was recorded in $92.4 \%$ males and $85.7 \%$ females. Attached earlobes were higher than the free earlobes in both sexes. Compared to the length of the ring finger, shorter index finger was prevalent both in males $(85.4 \%)$ and females $(68.6 \%)$. Frequencies of the broad lips in males and females were $53.4 \%$ and $58.6 \%$, respectively. Females dominated large and broad noses $(76.1 \%)$ in comparison with their male counterparts $(61.4 \%)$. Polydactyly was a rare trait in the Campus, where only $2.2 \%$ males and $0.2 \%$ females had extra digits in their hands or feet. Tongue rollers $(53.8 \%)$ outnumbered the tongue folders in males, but tongue folders (54.4\%) outnumbered the tongue rollers in females. Males with widow's peak were higher $(25.8 \%)$ than that in the females (19.0). Blood groups in the males and females were in the order: $B(32.0)>O(29.8)$ $>\mathrm{A}(22.4)>\mathrm{AB}(15.8)$ and $\mathrm{O}(34.8)>\mathrm{B}(34.4)>\mathrm{A}(21.9)>\mathrm{AB}(8.9)$, respectively. As a whole, $85.4 \%$ males and $98.0 \%$ females were $\mathrm{Rh}$-positive where the blood group phenotypes did not affect body weight, height and BMI of the subjects $(r=0.012$; $\mathrm{P}=0.63$ ). The relevance of these findings to the physical, physiological, social and clinical well-being of the humans has been discussed.
\end{abstract}

Key Words: Human traits, Body weight, Height, BMI, Blood groups, Rh-antigen, RU Campus.

*Author for corresponding: <saifulzoo.ru@gmail.com>

(c)2021 Zoological Society of Bangladesh DOI: https://doi.org/10.3329/bjz.v49i2.56259 


\section{INTRODUCTION}

Genetic traits in human beings are of two broad categories, namely, qualitative and quantitative. A qualitative trait is a trait that can be described as a discrete category, usually dominant or recessive and is controlled by oligogenes or major genes. Pattern baldness, attached or free earlobes, colour blindness, presence or absence of dimples on the cheek and widow's peak etc. are all qualitative traits (Novitski, 1977; Fankhauser, 2006). A quantitative trait, on the other hand, refers to a measurable phenotype that depends on the cumulative actions of polygenes or multiple factors and the environment. Traits such as height, weight, skin colour and IQ are quantitative which can vary among individuals, over a range, to produce a continuous distribution of phenotypes (McKusick, 1998). ABO blood groups and Rh (Rhesus) D antigen (positive or negative) are also qualitative in nature, but these are controlled by multiple alleles and pseudoalleles, respectively (Burns and Bottino, 1988; Daniels, 2013).

Islam and Rahman (2002) estimated the gene and genotype frequencies of some common human qualitative traits in 1000 male students from Rajshahi University (RU) Campus and Rahman and Islam (2002) reported family pedigree analyses of these traits in 257 people from several villages in Bogura, Bangladesh. Similarly, frequency of polydactyly (Biesecker, 2002), earlobes (Azaria et al., 2003), tongue rolling/folding ability (Odokuma et al., 2008), widow's peak (Nusbaum and Fuentefria, 2009), nose characteristics (Ordu et al., 2016), length of index finger (Kumar et al., 2017) and occurrence of dimples (Almaary et al., 2018) in different human populations have been reported. According to San Diego Supercomputer Center (SDSC, 2008), abundant or dense body hair is dominant over little or sparse body hair, baldness in males is dominant over non-bald, broad lips and broad nose are dominant over thin lips and narrow nose respectively, and polydactyly is dominant over normal. Nature of some common qualitative traits in man, however, has been dealt with in

Inherited Human Traits: A Reference (http://learn.genetics.utah.edu/teachers). Body mass index (BMI) is considered as the standard by which obesity and healthy weight are measured and defined (CDC, 2021). Reports on the body weight, height and BMI from Israel (Ginsburg et al., 1998) and Minnesota, USA (Nuttall, 2015) showed that BMI could be used for defining anthropometric height/weight characteristics in adults, which could also be used as a risk factor assessment for several health issues. Instead of BMI, however, Juntaping et al. (2017) used a height-weight difference index (HWDI) in Thailand as a new indicator for evaluating obesity status. Furthermore, Bhaskaran et al. (2018) demonstrated in a study in the UK that 
BMI had J-shaped associations with overall mortality and most specific causes of death, whereas lower BMI was associated with increased mortality risk. Gutin (2018) proposed BMI as a biomarker and a measure for a holistic appraisal of health. In a recent study in Canada, Andreacchi et al. (2021) compared obesity defined by BMI, waist circumference, waist-to-hip ratio, and percentage of body fat to estimate their associations with health care purposes. According to the current guidelines of the Centers for Disease Control and Prevention (CDC, 2021), BMI is used as a screening tool for overweight or obesity, where BMI $<18.5$ is regarded as underweight, 18.5-24.9 as normal, 25.0-29.9 as overweight and $\geq 30.0$ as obese.

Blood group is a classification of blood cells based on the presence or absence of inherited antigens on the surface of red blood cells (RBCs). The most important blood groups in man used for transfusion are the ABO blood group system that has $\mathrm{A}$ and $\mathrm{B}$ antigens and the Rh system that has many antigens of which $\mathrm{D}$ is the most important. An intensive survey of literature showed a huge number of studies on human blood groups and their implications. Thus, the findings of Kamil et al. (2010) in Libya; Zhang et al. (2012) in Minnesota, USA; Zaman et al. (2015) in Chittagong, Bangladesh; Deshpande and Wadde (2013), Singh et al. (2014), Tiwari et al. (2014) and Kumar et al. (2018) in various States of India; Maatoghi et al. (2016) in Iran; Alemu and Mama (2016) and Zerihun and Bekele (2016) in Ethiopia; Apecu et al. (2016) in Uganda; Jahanpour et al. (2017) in Tanzania; Smith et al. (2018) in Ghana, and very recently, Groot et al. (2020) in the UK and Zhao et al. (2020) in Wuhan and Shenzhen Provinces of China, have been reviewed and discussed.

In this study, the prevalence of 12 qualitative traits, three quantitative traits, four $\mathrm{ABO}$ blood groups and two Rh blood types have been recorded and analyzed from 500 male and 1000 female students of the RU Campus. The findings were aimed at updating the previous results on some common human traits recorded from RU and elsewhere in the country, which in turn, would be of considerable importance to the health professionals, psychologists, anthropologists and genetic variability researchers.

\section{MATERIAL AND METHODS}

Traits surveyed: A dozen of qualitative traits, viz., pattern baldness, body hair, chin, colour blindness, dimples on the cheek, earlobes, length of index finger, lips, nose, polydactyly (supernumerary digits in hands/feet), tongue rolling/folding ability, widow's peak, three quantitative traits, viz., body weight, body height and body mass index (BMI), and four ABO blood groups along with their Rh-D antigen (positive or negative), were recorded for estimating their 
prevalence in the students of the RU Campus. The traits of a total of 500 male students from 5 halls of residence and 1000 female students from 6 halls, all situated in the RU Campus, were collected individually through one-to-one personal interviews. The age of the subjects varied between 18 and 24 years and the study was conducted from July 2019 to February 2020.

Materials used: Photographs of dimples, earlobes, length of index finger, broad and thin lips, large and broad versus small and narrow noses, polydactyly, tongue rolling/folding, and widow's peak (a V-shaped point in the hairline in the centre of the forehead), were displayed to the subjects during interviews to identify the qualitative traits in them. A couple of Ishihara plates were used for the diagnosis of colour blindness. A portable clinical stadiometer was used for measuring body weight and height. The BMI of the subjects was then calculated using the formula: $\mathrm{BMI}=\mathrm{kg} / \mathrm{m}^{2}$, where $\mathrm{kg}$ is a person's weight in kilograms and $\mathrm{m}^{2}$ is his/her height in metres squared. Students having their confirmed blood groups, diagnosed either by the Rajshahi Medical College Hospital, Bangladesh Red Crescent Society or voluntary blood donors' organizations like 'Badhan' and 'Sandhani', were included in the study.

Statistical analyses: Simple arithmetic mean \pm SD and percentages were computed initially for the quantitative and qualitative traits, respectively. The quantitative data on body weight, height and BMI were then subjected to significance tests like Student's t-test and one-way analysis of variation (ANOVA) to quantify the mean differences. Pearson's product-moment co-efficient of correlation ( $r$ value) was used to determine the association between BMI and blood groups. SPSS (version 17.0) for Widows was used for statistical analyses.

\section{RESULTS AND DISCUSSION}

Data on the prevalence of 12 qualitative traits in the RU students (Table 1) revealed the following details.

Pattern baldness: About one-sixth portion (15.8\%) of the male students possessed baldness as compared with none of the female counterparts. Body hair: Sparse body hair was prevalent over the dense body hair in both genders, where male and female students had respectively $42.4 \%$ and $33.2 \%$ dense body hairs. Chin: Female students had much higher smooth chin $(89.6 \%)$ than the male students $(58.0 \%)$ but the males had much higher cleft chin $(42.0 \%)$ compared to the females (10.4\%). Colour blindness: Although none of the female students possessed this trait, only $7.4 \%$ male students were found colourblind.

Cheek dimples: Absence of dimples was higher in males (92.4\%) who had

$6.6 \%$ double (bilateral) dimples and only $1 \%$ single (unilateral) dimple. Absence 
of dimples in females, on the other hand, was $85.7 \%$ but the frequencies of both double $(12.0 \%)$ and single $(2.3 \%)$ dimples in them were much higher than those in the males. Earlobes: Attached earlobes were much higher than the free earlobes in both sexes, where the females had $76.4 \%$ compared to $56.6 \%$ in males. So, the free earlobes in the males $(43.4 \%)$ were almost double than their female partners $(23.6 \%)$. Length of index finger: Compared to the length of the ring finger (4th digit or 4D), shorter index finger (2nd digit or 2D) was prevalent both in males $(85.4 \%)$ and females $(68.6 \%)$ in comparison with the longer index finger in the student population under study.

Lips: Differences in frequencies of the broad versus thin lips were not much higher in the subjects with regard to their gender, where the males had $53.4 \%$ and the females had $58.6 \%$ broad lips. Nose: Females had considerably higher proportions of large and broad noses $(76.1 \%)$ in comparison with their male counterparts $(61.4 \%)$, who bore higher percentage of small and narrow noses $(38.6 \%)$ than those in the females $(23.9 \%)$. Polydactyly: Persons with polydactyly were comparatively rare in the Campus, where only a negligible proportion of the male $(2.2 \%)$ and female $(0.2 \%)$ students had extra digits in their hands/feet. Tongue rolling/folding ability: In the male students, tongue rollers (53.8\%) outnumbered the tongue folders, whereas in the female students, interestingly, the frequency of tongue folders (54.4\%) was higher than that of the tongue rollers. Widow's peak: Although the prevalence of widow's peak was higher in males $(25.8 \%)$ than in females (19.0), the overall occurrence of the trait was slightly above one-fifth $(21.67 \%)$ of the total students under survey.

Results of the three quantitative traits of the RU students under study are presented in Table 2 . The mean $\pm \mathrm{SD}$ body weights of the male students $(66.42 \pm 8.92 \mathrm{~kg})$ were significantly higher $(\mathrm{t}=35.14 ; \mathrm{P}<0.001)$ than those of the female students $(51.64 \pm 6.97 \mathrm{~kg})$. The body weight in the males ranged between 45.11 and $89.01 \mathrm{~kg}$, while the trait in females was found to vary from 35.23 to $90.33 \mathrm{~kg}$. The differences between the average heights of the two groups of students $(1.69 \pm 0.08 \mathrm{~m}$ and $1.59 \pm 0.04 \mathrm{~m}$ respectively) were highly significant $(\mathrm{t}=$ 5.21; $\mathrm{P}<0.001)$, where the male heights ranged between 1.52 and $1.89 \mathrm{~m}$ compared to the female heights ranging between 1.42 and $1.55 \mathrm{~m}$. The differences in BMI values between males (23.32 \pm 3.26$)$ and females $(20.85 \pm 2.63)$, as expected, were also highly significant $(\mathrm{t}=15.79 ; \mathrm{P}<0.001)$, where both groups were composed of normal $(\mathrm{BMI}=18.5-24.9)$, overweight $(\mathrm{BMI}=25.0-29.9)$ and obese (BMI $\geq 30.0)$ persons. Notably, some of the female students belonged to the underweight category $(\mathrm{BMI}<18.5)$.

As expected, hall-wise variations for the quantitative traits in male students were not significant. ANOVA for weight, height and BMI showed $F_{4,499}=2.185$ 
Table 1. Variations in the qualitative traits between male and female students of the RU Campus, Bangladesh

\begin{tabular}{|c|c|c|}
\hline Qualitative traits & $\begin{array}{c}\text { Male students } \\
(\mathbf{5 0 0 )})\end{array}$ & $\begin{array}{c}\text { Female students } \\
(1000)\end{array}$ \\
\hline \multicolumn{3}{|l|}{ Pattern baldness } \\
\hline Absent & $421(84.2)$ & 1000 (100.0) \\
\hline Present & $79(15.8)$ & $0(0.0)$ \\
\hline \multicolumn{3}{|l|}{ Body hair } \\
\hline Sparse & 288 (57.6) & $668(66.8)$ \\
\hline Dense & 212 (42.4) & 332 (33.2) \\
\hline \multicolumn{3}{|l|}{ Chin } \\
\hline Smooth & 290 (58.0) & 896 (89.6) \\
\hline Cleft & 210 (42.0) & 104 (10.4) \\
\hline \multicolumn{3}{|l|}{ Colour blindness } \\
\hline Normal vision & $463(92.6)$ & 1000 (100.0) \\
\hline Colourblind & $37(7.4)$ & $0(0.0)$ \\
\hline \multicolumn{3}{|l|}{ Cheek dimples } \\
\hline Absent & $462(92.4)$ & 857 (85.7) \\
\hline Single & $33(6.6)$ & $120(12.0)$ \\
\hline Double & $5(1.0)$ & $23(2.3)$ \\
\hline \multicolumn{3}{|l|}{ Earlobes } \\
\hline Attached & 283 (56.6) & 764 (76.4) \\
\hline Free & 217 (43.4) & 236 (23.6) \\
\hline \multicolumn{3}{|c|}{ Length of index finger } \\
\hline Shorter & 427 (85.4) & 686 (68.6) \\
\hline Longer & 73 (14.6) & 314 (31.4) \\
\hline \multicolumn{3}{|l|}{ Lips } \\
\hline Broad & 267 (53.4) & $586(58.6)$ \\
\hline Thin & 233 (46.6) & $414(41.4)$ \\
\hline \multicolumn{3}{|l|}{ Nose } \\
\hline Large \& broad & 307 (61.4) & $761(76.1)$ \\
\hline Small \& narrow & 193 (38.6) & 239 (23.9) \\
\hline \multicolumn{3}{|l|}{ Polydactyly } \\
\hline Absent & 489 (97.8) & 998 (99.8) \\
\hline Present & $11(2.2)$ & $2(0.2)$ \\
\hline \multicolumn{3}{|l|}{ Tongue } \\
\hline Rollers & $269(53.8)$ & $456(45.6)$ \\
\hline Folders & 231 (46.2) & 544 (54.4) \\
\hline \multicolumn{3}{|l|}{ Widow's peak } \\
\hline Absent & $371(74.2)$ & $810(81.0)$ \\
\hline Present & $129(25.8)$ & $190(19.0)$ \\
\hline
\end{tabular}

Figures in the parentheses indicate percentages.

$(\mathrm{P}=0.070), \mathrm{F}_{4,499}=0.314(\mathrm{P}=0.868)$ and $\mathrm{F}_{4,499}=1.963(\mathrm{P}=0.099)$, respectively. The same was also true for female students as well, where the calculated values were $\mathrm{F}_{5,999}=0.855(\mathrm{P}=0.511), \mathrm{F}_{5}, 999=0.572(\mathrm{P}=0.722)$ and $\mathrm{F}_{5}, 999=0.091(\mathrm{P}=0.994)$, respectively. Correlation between body weight and height in the combined population $(\mathrm{N}=1500)$ was significant one $(\mathrm{r}=0.124 ; \mathrm{P}<0.01)$; that in the male population $(\mathrm{N}=500)$ was also significant $(\mathrm{r}=0.290$ : $\mathrm{P}<0.01)$; but interestingly, correlation between these two variables in the female population $(\mathrm{N}=1000)$ was statistically not significant $(\mathrm{r}=0.029 ; \mathrm{P}=0.334)$. 
Table 2. Variations in the quantitative traits between male and female students of the RU Campus, Bangladesh

\begin{tabular}{llll}
\hline Quantitative traits & \multicolumn{1}{c}{$\begin{array}{c}\text { Male students } \\
(\mathbf{N}=\mathbf{5 0 0 )}\end{array}$} & $\begin{array}{c}\text { Female students } \\
(\mathbf{1 0 0 0 )}\end{array}$ & t-values* (P) \\
\hline Body weight (kg) & $66.42 \pm 8.92$ & $51.64 \pm 6.97$ & $35.14(<0.001)$ \\
Range (Min-Max) & $45.11-89.01$ & $35.23-90.33$ & - \\
Height (m) & $1.69 \pm 0.08$ & $1.59 \pm 0.04$ & $5.21(<0.001)$ \\
Range (Min-Max) & $1.52-1.89$ & $1.42-1.55$ & - \\
Body mass index & $23.32 \pm 3.26$ & $20.85 \pm 2.63$ & $15.79(<0.001)$ \\
(BMI) & & & \\
Range (Min-Max) & $18.92-33.15$ & $18.22-33.01$ & - \\
\hline
\end{tabular}

*All t-values are at $1498 \mathrm{df}$; Current guidelines for BMI: <18.5 is underweight, 18.5-24.9 is normal 25.0-29.9 is overweight and $\geq 30.0$ is obese (CDC, 2021).

Table 3 shows data on the ABO blood groups and Rh-D antigen variations in the studied population. Irrespective of the $\mathrm{Rh}$ antigen, blood groups in the male students were in the order: $\mathrm{B}(32.0)>\mathrm{O}(29.8)>\mathrm{A}(22.4)>\mathrm{AB}(15.8)$. In the female students, however, the order was: $\mathrm{O}(34.8)>\mathrm{B}(34.4)>\mathrm{A}(21.9)>\mathrm{AB}$ (8.9). In males, the most frequent blood group was $B+(28.6 \%)$ and the least frequent was $\mathrm{AB}-(1.4 \%)$, whereas in females, $\mathrm{B}+$ and $\mathrm{O}+(33.8 \%$ each) were the most frequent and $\mathrm{AB}-(0.1 \%)$ was the least frequent blood group. As a whole, therefore, $85.4 \%$ males and $98.0 \%$ females were Rh-positive as compared with $14.6 \%$ males and only $2.0 \%$ Rh-negative females.

Table 3. Variations in the blood groups between male and female students of the RU Campus, Bangladesh

\begin{tabular}{clll}
\hline Blood groups & Rh-antigens & Male students (N=500) & Female students (N=1000) \\
\hline \multirow{2}{*}{ A } & Rh-positive & $90(18.0)$ & $216(21.6)$ \\
& Rh-negative & $22(4.4)$ & $3(0.3)$ \\
& Total & $\mathbf{1 1 2}(\mathbf{2 2 . 4 )}$ & $\mathbf{2 1 9 ( 2 1 . 9 )}$ \\
& Rh-positive & $143(28.6)$ & $338(33.8)$ \\
$\mathrm{B}$ & Rh-negative & $17(3.4)$ & $6(0.6)$ \\
& Total & $\mathbf{1 6 0 ( 3 2 . 0 )}$ & $\mathbf{3 4 4}(\mathbf{3 4 . 4 )}$ \\
$\mathrm{AB}$ & Rh-positive & $72(14.4)$ & $88(8.8)$ \\
& Rh-negative & $7(1.4)$ & $1(0.1)$ \\
& Total & $\mathbf{7 9 ( 1 5 . 8 )}$ & $\mathbf{8 9 ( 8 . 9 )}$ \\
$\mathrm{O}$ & Rh-positive & $122(24.4)$ & $338(33.8)$ \\
\multirow{2}{*}{ Overall } & Rh-negative & $27(5.4)$ & $10(1.0)$ \\
& Total & $\mathbf{1 4 9}(\mathbf{2 9 . 8 )}$ & $\mathbf{3 4 8}(\mathbf{3 4 . 8})$ \\
& Rh-positive & $427(85.4)$ & $980(98.0)$ \\
& Rh-negative & $73(14.6)$ & $20(2.0)$ \\
\hline
\end{tabular}

Figures in the parentheses indicate percentages.

Association between BMI and blood groups in the student groups of the RU Campus was not significant one (Pearson's $r=0.012$; $\mathrm{P}=0.63$ ), thus suggesting that the blood group antigens did not affect the quantitative traits like body weight, height and BMI of the individuals under study. 
Pattern baldness or hair loss/absence of hair, which is most noticeable on the scalp, is due to a combination of genetic and hormonal effect and therefore is regarded as a sex-influenced trait (Randall, 1994; Burns and Bottino, 1988). Differences exist in the amount and distribution of hair loss between genders, races and ethnic groups of people (Nalluri and Harries, 2016). This is obvious from the present data where $15.8 \%$ of the males possessed this trait as compared with none of the females. Since the growth of body hair in human is related to the level of and rogens and the density of androgen receptors in the dermal papillae (Burns and Bottino, 1988), male students of the present study possessed higher proportions of dense body hair $(42.4 \%)$ compared to their female partners $(33.2 \%)$. Cleft chin is reported to inherit as dominant and smooth chin as recessive (Winchester, 1972; Schwartz and Tattersall, 2000). Here, $42.0 \%$ males had cleft chin in comparison with only $10.4 \%$ females, who had much higher proportion $(89.6 \%)$ of smooth chin.

Red-green colour blindness is the most common form of colour vision deficiency which affects men much more often than women. In Northern European populations, it occurs in about 1 in 12 males $(=8.33 \%)$ and 1 in 200 females $(=0.5 \%)$ but have a lower incidence in almost all other populations studied (Novitski, 1977). It is reported that 2 out of every 25 white males $(=8 \%)$ are red-green colour blind, but only about 1 in 150 females $(=0.67 \%)$ is so affected (Burns and Bottino, 1988). In contrast, $7.4 \%$ male students were colourblind in the RU Campus. In a study of 216 people aged between 18 and 42 years, 120 (55.6\%) had dimples in both of their cheeks (Almaary et al., 2018). This is obviously quite contrasting to the present result, where $12.0 \%$ females had double and $2.3 \%$ had single dimples compared to $6.6 \%$ and $1.0 \%$ double and single dimples, respectively in males. Some scientists have reported that earlobe attachment is due to a single gene for which free earlobe is dominant and attached earlobe is recessive. But others suggest that this trait is influenced by several genes (Azaria et al., 2003). However, following frequencies of attached earlobes in various populations have been reported (https://en.wikipedia.org/wiki/Earlobe): Africa 0.60, Brazil 0.34, Hong Kong 0.80, West Bengal (India) 0.66, Russia 0.59, Buffalo (USA) 0.43 and Pennsylvania (USA) 0.50. In agreement with the above variable data, $76.4 \%$ female and $56.6 \%$ male students of the RU Campus had attached earlobes.

The difference in length between the index finger ( $2^{\text {nd }}$ digit or $\left.2 \mathrm{D}\right)$ and the ring finger (4th digit or 4D) is expressed as the 2D:4D ratio, where men have lower values compared to that of women (Kumar et al., 2017). This has been reflected in the present study, where shorter 2D was prevalent both in males $(85.4 \%)$ and females $(68.6 \%)$ in comparison with the longer 4D in $14.6 \%$ males 
and $31.4 \%$ females. In accord with the finding that broad lips are prevalent over thin lips (SDSC, 2008), 53.4\% males and 58.6\% females of the RU Campus had broad lips. Broad nose was more frequent $(88.4 \%)$ when compared to narrow nose $(11.6 \%)$, and $46.9 \%$ of males had broad nose against $41.5 \%$ of females in a Nigerian study (Ordu et al., 2016). Unlike these results, however, $76.1 \%$ females had large and broad noses in comparison with $61.4 \%$ male counterparts, which could be due to racial differences. Although a dominant trait, the expression of polydactyly in humans is relatively rare, diverse and heterogeneous (Biesecker, 2002; Fankhauser, 2006). This has been the case in the present survey, where $2.2 \%$ males and only $0.2 \%$ females were polydactylous.

In a study conducted amongst the students of Delta State University of Nigeria by Odokuma et al. (2008), the frequency of tongue folders $(83.92 \%)$ and tongue rollers $(60.84 \%)$ were more common than non-folders $(16.08 \%)$ and nonrollers $(39.16 \%)$. This lends support to the present male students, where tongue rollers $(53.8 \%)$ outnumbered the tongue folders. But in the female students, in the contrary, the frequency of tongue folders (54.4\%) was higher than that of the tongue rollers. A widow's peak, in contrast to a straight hairline, is reported to inherit as a dominant trait (Winchester, 1972; Fankhauser, 2006). A study conducted by Nusbaum and Fuentefria (2009) found that $81 \%$ women had a widow's peak. This finding is dissimilar to the present results where $25.8 \%$ males and $19.0 \%$ females were found to possess widow's peak.

Body weight, height and BMI were assessed from 1811 individuals of multiracial ancestry in Israel (Ginsburg et al., 1998) where the results showed $17-53 \%$ variations in the traits. Nuttall (2015) observed an age-related wide range of BMI values in Minnesota, USA. From a study in Thailand, Juntaping et al. (2017) suggested that the height-weight difference index could be an easy-touse obesity evaluation tool that could help awareness of underweight and obesity conditions. Bhaskaran et al. (2018) observed in the UK that higher BMI was associated with overall mortality and most specific causes of death, while lower BMI was associated with increased mortality risk. In a North Carolina study in USA, Gutin (2018) proposed BMI as a biomarker that could be used for a holistic appraisal of health independent of medical authorities. The present results conform to those of the aforesaid findings in that male and female subjects exhibited significant differences in body weight, height and BMI values regarding their underweight, normal, overweight or obesity status, which give an impression of their physical, physiological, social and mental well-being.

Numerous reports on the frequencies of $\mathrm{ABO}$ blood groups and their Rh-D antigens indicate that frequencies of these traits vary tremendously owing to continents, races and ethnic origins. In Latur, India, for example, Deshpande 
and wadde (2013) identified $95.19 \% \mathrm{Rh}$-positive and $4.81 \% \mathrm{Rh}$-negative donors, who had the following blood group distribution: B (37.98 \%)> O (27.64\%)> A $(24.89 \%)>\mathrm{AB}(9.47 \%)$. In Gwalior, India, on the other hand, Tiwari et al. (2014) recorded the following order of prevalence: $\mathrm{O}(31.09 \%)>\mathrm{B}(30.25 \%)>\mathrm{A}(28.57 \%)>$ $\mathrm{AB}(10.09 \%)$, who belonged to $92.43 \%$ Rh-positive and $7.57 \%$ Rh-negative. In New Delhi, India, however, Kumar et al. (2018) assessed the following order: B > $\mathrm{A}>\mathrm{O}>\mathrm{AB}$ in males and $\mathrm{B}>\mathrm{O}>\mathrm{A}>\mathrm{AB}$ in females and the population consisted of $90.72 \%$ Rh-positive and $9.28 \%$ Rh-negative individuals. While in Chittagong City Corporation, Bangladesh, Zaman et al. (2015) recognized the following order of prevalence: $\mathrm{B}>\mathrm{O}>\mathrm{A}>\mathrm{AB}$ in males but $\mathrm{O}>\mathrm{A}>\mathrm{B}>\mathrm{AB}$ in females, and the population was composed of $90.72 \%$ Rh-positive and $9.28 \%$ Rh-negative persons.

In African countries, Alemu and Mama (2016) observed 92.8\% Rh-positive in South Ethiopia, where the $\mathrm{ABO}$ phenotypes were in decreasing order of: $\mathrm{O}$ $(42.1 \%)>$ A $(32.7 \%)>$ B $(20.9 \%)>$ AB (4.3\%); Apecu et al. (2016) in Uganda recorded 98\% Rh-positive versus $2 \%$ Rh-negative blood donors where the distribution was: $\mathrm{O}(50.3 \%)>\mathrm{A}(24.6 \%)>\mathrm{B}(20.7 \%)>\mathrm{AB}(4.5 \%)$; S-W Ethiopia had the following prevalence: $\mathrm{O}(43.1 \%)>\mathrm{A}(31.9 \%)>\mathrm{B}(21.5 \%)>\mathrm{AB}(3.5 \%)$, with 92.8\% subjects Rh-positive and 7.2\% Rh-negative (Zerihun and Bekele, 2016); a study in Tanzania by Jahanpour et al. (2017) revealed that the most common blood group was $\mathrm{O}(52.3 \%)$ and the least common was $\mathrm{AB}(3.18 \%)$., where $97.7 \%$ of the blood donors were Rh-positive and the rest $2.3 \%$ were $\mathrm{Rh}$-negative; and Smith et al. (2018) found O blood group as the most prevalent (51.2\%) and Rhpositive individuals constituted $90.3 \%$ amongst a university students in Ghana. Maatoghi et al. (2016), on the other hand, recognized highly variable blood group frequencies in different Iranian provinces and ethnics with an overall prevalence of $\mathrm{O}>\mathrm{A}=\mathrm{B}>\mathrm{AB}$. Furthermore, in a recent study using the UK Biobank cohort of 406755 unrelated individuals data, Groot et al. (2020) reported 44.9\% O, 44.9\% A and $10.2 \%$ B, while AB was excluded because of its relative small sample size. The above findings are appreciably different from the present results where 85.4\% males and $98.0 \%$ females were Rh-positive as compared with $14.6 \%$ males and $2.0 \%$ Rh-negative females. Apart from these, the male students showed the following blood group frequencies: $\mathrm{B}(32.0 \%)>\mathrm{O}(29.8 \%)>\mathrm{A}(22.4 \%)$ $>\mathrm{AB}(15.8 \%)$ compared to the females: $\mathrm{O}(34.8 \%)>\mathrm{B}(34.4 \%)>\mathrm{A}(21.9 \%)>\mathrm{AB}$ $(8.9 \%)$. Again, in males, the most frequent blood group was $\mathrm{B}+(28.6 \%)$ and the least frequent was $\mathrm{AB}-(1.4 \%)$, whereas in females, $\mathrm{B}+$ and $\mathrm{O}+(33.8 \%$ each) were the most frequent and $\mathrm{AB}-(0.1 \%)$ was the least frequent blood group. The probable explanation for these variations might be owing to racial and/or ethnic factors. Finally, regarding the association between BMI and blood groups, the 
present results are similar to a previous study in Ghana, where overweight and obesity were neither associated with $\mathrm{ABO}$ blood groups nor with Rh-D antigen (Smith et al., 2018).

Significance of the studies on qualitative and quantitative traits as well as blood groups in human societies could be of overwhelming importance. Qualitative traits are useful in certain forensic and genetic studies (Ordu et al., 2016). Moreover, traits like baldness, body hair, chin, dimples, earlobes, lips, nose, polydactyly and widow's peak might be valuable for marital and/or social preferences. The quantitative trait BMI, for example, could be used as a biomarker for an appraisal of health conditions independent of medical authorities (Gutin, 2018), and higher BMI is correlated with most specific causes of death and overall mortality, and lower BMI is also associated with increased mortality risk (Bhaskaran et al., 2018). The prevalence of overweight and obesity were observed among blood group $\mathrm{O}$ and Rh-positive students (Smith et al., 2018).

Blood groups play significant role in blood transfusion, medico-legal cases including settlement of paternity disputes and organ transplantation. Certain blood groups like A and O have fewer chances of Type II diabetes mellitus (Kamil et al., 2010) and there is association between A, B and AB blood groups and an increased risk of some cardiovascular disorders (Zhang et al., 2012). Moreover, ABO blood incompatibility between mother and foetus may produce infertility or haemolytic disease of the new born, and persons of certain blood groups have an increased susceptibility to peptic ulcer or gastric cancer (Singh et al., 2014). Asymptomatic malaria called parasitemia (Alemu and Mama, 2016), prevention of diseases like hypertension and thromboembolic events (Groot et al., 2020), and a higher risk for acquiring COVID-19 for persons with blood group A compared to non-A persons (Zhao et al., 2020) are some of the other important aspects of blood group studies.

\section{CONCLUSION}

The present study provides an update to previous reports from this lab by Islam and Rahman (2002) and Rahman and Islam (2002) on some common human traits in the students of RU Campus and some village people from Bogura, Bangladesh, where only frequencies of some qualitative traits and their inheritance were evaluated. Qualitative traits and blood groups are included in the present report, and all the findings are supposed to help both public and private social and health professionals in the country to prepare database and increase student awareness regarding the impacts of these easily detectable genetic traits in human beings. 
Acknowledgements: The authors are grateful to the subjects for their consents, time and for allowing personal information needed for the survey. This forms part of the undergraduate dissertations by AAS, SA and BB. Contributions of the authors of the relevant textbooks and internet sources for their plates and photographs used in the research are thankfully acknowledged.

\section{LITERATURE CITED}

ALEMU, G. and MAMA, M. 2016. Assessing ABO/Rh blood group frequency and association with asymptomatic malaria among blood donors attending Arba Minch Blood Bank, South Ethiopia. Malaria Res. Treat. Article ID 8043768, 7 pages http://dx.doi.org/10.1155/2016/ 8043768.

ALMAARY, H.F., SCOTT, C. and KARTHIK, R. 2018. New landmarks for the surgical creation of dimples based on facial form. J. Clinical Aesth. Dermatol. 11 (5): 22-26.

ANDREACCHI, A.T., GRIFFITH, L.E., GUINDON, G.E. et al. 2021. Body mass index, waist circumference, waist-to-hip ratio, and body fat in relation to health care use in the Canadian Longitudinal Study on Aging. Int. J. Obes. https://doi.org/10.1038/s41366-020-00731-z.

APECU, R.O., MULOGO, E.M., BAGENDA, F. and BYAMUNGU, A. 2016. ABO and Rhesus (D) blood group distribution among blood donors in rural south western Uganda: a retrospective study. BMC Res. Notes 9: 513. doi: 10.1186/s13104-016-2299-5.

AZARIA, R., ADLER, N., SILFEN, R., REGEV D. and HAUBEN, D. 2003. Morphometry of the adult human earlobe: A study of 547 subjects and clinical application. Plastic Reconstr. Surg. 111(7): 2398-2402.

BHASKARAN, K., dos-SANTOS-SILVA, I., LEON, D.A., DOUGLAS, I.J. and SMEETH, L. 2018. Association of BMI with overall and cause-specific mortality: a population-based cohort study of 3.6 million adults in the UK. Lancet Diabetes Endocrinol. 6: 944-953.

BIESECKER, L.G. 2002. Polydactyly: How many disorders and how many genes? Am. J. Med. Genet. 112: $279-283$.

BURNS, G.W. and BOTTINO, P.J. 1988. The Science of Genetics (6 $6^{\text {th }}$ edn). Benjamin Cummings, USA. $491 \mathrm{pp}$.

CDC (Centers for Disease Control and Prevention) 2021. https://www.cdc.gov/obesity/adult/

DANIELS, G. 2013. Human Blood Groups (3 $3^{\text {rd }}$ edn). Wiley Online Library. https://onlinelibrary.wiley.com/doi/book/10.1002/9781118493595

DESHPANDE, R.H. and WADDE, S.K. 2013. Distribution of blood groups in blood donors in blood banks of Latur. Sch. J. App. Med. Sci. 1(4): 276-279.

FANKHAUSER, D.B. 2006. Human heritable traits. Available at http://biology.clc.uc.edu/fankhauser/ labs/BioLab_112/Human_Genetics.html 
GINSBURG, E., LIVSHITS, G., YAKOVENKO, K. and KOBYLIANSKY, E. 1998. Major gene control of human body height, weight and BMI in five ethnically different populations. Ann. Hum. Genet. 62: 307-322.

GROOT, H.E., SIERRA, L.E.V., SAID, M.A., LIPSIC, E., KARPER, J.C. and van der HARST, P. 2020. Genetically determined ABO blood group and its associations with health and disease. Arterioscler. Thromb. Vasc. Biol. 40: 830-838.

GUTIN, I. 2018. In BMI we trust: Reframing the body mass index as a measure of health. Soc. Theory Health 16(3): 256-271.

INHERITED HUMAN TRAITS: A QUICK REFERENCE 2006. University of Utah, USA. https://teach.genetics.utah.edu/content/heredity/

ISLAM, M.S. and RAHMAN, M.A. 2002. Incidence of some common genetic traits and their inheritance in male students of Rajshahi University Campus. J. Asiat. Soc. Bangladesh, Sci. 28(1): $111-118$.

JAHANPOUR, O., PYUZA, J.J., NTIYAKUnZE, E.O., MREMI, A. and SHAO, E.R. 2017. ABO and Rhesus blood group distribution and frequency among blood donors at Kilimanjaro Christian Medical Center, Moshi, Tanzania. BMC Res. Notes 10: 738. https://doi.org/10.1186/s13104017-3037-3.

JUNTAPING, K., CHITTAWATANARAT, K., PRASITWATTANASEREE, S., CHAIJARUWANICH, J. and TRAISATHIT, P. 2017. Relationship between height-weight difference index and body-fat percentage estimated by bioelectrical impedance analysis in Thai adults. Sci. World J. Article ID 7258607, 8 pages, https://doi.org/10.1155/2017/7258607

KAMIL, M., AL-JAMAL, H.A.N. and YUSOFF, N.M. 2010. Association of ABO blood groups with diabetes mellitus. Libyan J. Med. 5: 4847. doi: 10.3402/ljm.v5i0.4847.

KUMAR, S., MODAK, P.K., ALI, S.H., BARPANDA, S.K., GUSAIN, V.S. and ROY, R. 2018. A retrospective study: $\mathrm{ABO}$ and $\mathrm{Rh}$ phenotype bloodngroup distribution among blood donors in H.N.B. Basen Hospital, Srinagar, Uttarakhand, India. J. Family Med. Prim. Care 7: 34-38.

KUMAR, S., VORACEK, M. and SINGH, M. 2017. Sexual dimorphism in digit ratios derived from dorsal digit length among adults and children Front. Endocrinol. 8: 41. doi: 10.3389 /fendo.2017.00041.

MAATOGHI, J.T., PARIDAR, M., SHOUSHTARI, M.M., KIANI, NORI, B., SHAHJAHANI, M., KHOSRAVI, A., KELARIJANI, N.A., GHALESARDI, O.K. and FAR, M.A.J. 2016. Distribution of ABO blood groups and rhesus factor in a large scale study of different cities and ethnicities in Khuzestan province, Iran. Egyptian J. Med. Human Genet. 17: 105-109.

MCKUSICK, V.A. 1998. Mendelian Inheritance in Man: A Catalog of Human Genes and Genetic Disorders (12 ${ }^{\text {th }}$ edn). John Hopkins University Press, USA. 3972 pp.

NALLURI, R. and HARRIES, M. 2016. Alopecia in general medicine. Clin. Med. 16(1): 74-78.

NOVITSKI, E. 1977. Human Genetics. MacMillan Publishers Ltd., USA. 458 pp. 
NUSBAUM, B.P. and FUENTEFRIA. S. 2009. Naturally occurring female hairline patterns. Dermatologic Surgery 35: 907-913.

NUTTALL, F.Q. 2015. Body mass index. Obesity, BMI and health: A critical review. Nutr. Today 50(3): 117-128.

ODOKUMA, E.I., EGHWORO, O., AVWIORO, G. and AGBEDIA, U. 2008. Tongue rolling and tongue folding traits in an African population. Int. J. Morphol. 26(3): 533-535.

ORDU, K.S., AIGBOGUN, E.O. and NWANKWO, J.C. 2016. Evaluation of nose shape as a Mendelianinherited trait in the determination of parentage among Nigerians in Port Harcourt. J. Exp. Clin. Anat. 15: 9-13.

RAHMAN, M.A. and ISLAM, M.S. 2002. Family pedigree analyses of some common traits in man. Bangladesh J. Zool. 30: 195-199.

RANDALL, V.A. 1994. Androgens and human hair growth. Clin. Endocrinol. 40: 439-457.

SAN DIEGO SUPERCOMPUTER CENTER (SDSC) 2008. Mendelian Traits in Man. In: Human Genetics. http://education.sdsc.edu/download/enrich/mendelian_traits.pdf

SCHWARTZ, J.H. and TATTERSALL, I. 2000. The human chin revisited: what is it and who has it? $J$. Hum. Evol. (2000) 38: 367-409.

SINGH, P.A., RATHOD, S.S., KODUMURU, P.K., DESAI, J.M. and NAGOSE, V. 2014. A complete review article on ABO blood groups. Asian J. Health Sci. 2: 54-58.

SMITH, S., OKAI, I., ABAIDOO, C.S. and ACHEAMPONG, E. 2018. Association of ABO blood group and body mass index: A cross-sectional study from a Ghanaian population. J. Nutr. Met. https://doi.org/10.1155/2018/8050152.

TIWARI, R., JAIN, V., RAJPUT, A.S., GOYAL, M., BHARGO, L. and JAIN, S. 2014. A study to assess prevalence of blood groups in II semester medical students of G. R. Medical College Gwalior MP, India. Int. J. Res. Health Sci. 2(2): 555-562.

WINCHESTER, A.M. 1972. Human Genetics. Charles E. Merrill Publishing Co. Columbus, Ohio. 182 pp.

ZAMAN R., PARVEZ, M., JAKARIA. M. and SAYEED, M.A. 2015. Study of ABO and Rh-D blood group among the common people of Chittagong city corporation area of Bangladesh. J. Pub. Health Epidemiol. 7(9): 305-310.

ZERIHUN, T. and BEKELE, S. 2016. Pattern of ABO and Rhesus blood groups distribution of five years survey in Jimma Town Blood Bank, South West Ethiopia. J. Health Edu. Res. Dev. 4(3). doi: 10.4172/2380-5439.1000177.

ZHANG, H., MOONEY, C.J. and REILLY, M.P. 2012. ABO blood groups and cardiovascular diseases. Int. J. Vas. Med. Article ID 641917, 11 pages doi:10.1155/2012/641917.

ZHAO, J., YANG, Y., HUANG, H., LI, D., GU, D., LU, X., ZHANG, Z., LIU, L., LIU, T. et al. 2020. Relationship between the ABO blood group and the COVID-19 susceptibility. medRxiv preprint doi: https://doi.org/10.1101/2020.03.11.20031096.

(Manuscript received on 10 March, 2021 revised on 1June, 2021) 